\title{
Tax Ethics and Tax Evasion, Evidence from Greece
}

\author{
George Drogalas ${ }^{*}$, Evgenia Anagnostopoulou${ }^{1}$, Michail Pazarskis $^{2}$, Dimitrios Petkopoulos ${ }^{3}$ \\ ${ }^{1}$ Department of Business Administration, University of Macedonia, Thessaloniki, Greece \\ ${ }^{2}$ Department of Accounting \& Finance, Technological Educational Institute of Central Macedonia, Serres, Greece \\ ${ }^{3}$ Ministry of Finance, Giannitsa, Greece \\ Email: *drogalas@uom.gr
}

How to cite this paper: Drogalas, G., Anagnostopoulou, E., Pazarskis, M. and Petkopoulos, D. (2018) Tax Ethics and Tax Evasion, Evidence from Greece. Theoretical Economics Letters, 8, 1018-1027. https://doi.org/10.4236/tel.2018.85070

Received: February 5, 2018

Accepted: March 10, 2018

Published: April 16, 2018

Copyright (c) 2018 by authors and Scientific Research Publishing Inc. This work is licensed under the Creative Commons Attribution International License (CC BY 4.0).

http://creativecommons.org/licenses/by/4.0/

cc) (i) Open Access

\begin{abstract}
Tax evasion involves the deliberate act of noncompliance to tax legislation and the disregard of tax payments from the citizens. Moreover, many citizens do not directly violate tax legislation, but avoid paying taxes by taking advantage the lack of explicit legislation. Along those lines, tax ethics forms a personal constraint which regulates the way citizens behave regarding the payment of taxes. The purpose of this paper is to explore the tax ethics of Greek citizens and to compare them with those of other countries. In order to compare our results with those of other countries, we used a questionnaire, developed by Prof. Robert W. McGee, which has been used as a research instrument in similar studies. Our results show that Greek citizens do not evade taxes due to potential personal gains but rather because they believe that the state is incapable of proper allocation of public money and that the current political and tax system is inefficient or corrupt. In conclusion, the state has to gain the trust of its citizens in order to increase tax ethics and tackle tax evasion, by allocating its resources efficiently and by promoting political transparency.
\end{abstract}

\section{Keywords}

Tax Ethics, Tax Evasion, Auditing, Accounting, Greece

\section{Introduction}

Withholding information regarding one's income in order to pay less tax has moral and legal implications [1]. The state needs sources of income, in order to be able to offer services and provide security to its citizens. On the other hand, the government frequently wastes public money due to inefficient management and sometimes due to illegal abuse. Consequently, citizens deviate from the legal 
procedure regarding the payment of taxes, while the government sometimes crosses the limits of good public administration.

Since 2008, in the light of the economic crisis, more strict measures have been taken regarding the detection of "concealed" income [2]. In this scope, governing practices regarding tax revenue collection have been developed in the European Union (EU). Moreover, exchange of information regarding "concealed" income is also promoted between member states and countries such as Switzerland, Monaco, San Marino and Liechtenstein [3]. During the last years, the European Parliament has greatly contributed on the implementation of initiatives regarding the mitigation of tax evasion and money laundering from illegal activities [4]. As a result, governments in the EU have enacted and enforced more sophisticated legislation against tax evasion. Greece has a very strict legal system. However, the current "overregulation" often results in contradictions between various laws and law complexity, which enhances tax evasion. At the same time, there is a significant decrease in VAT revenue in Greece, compared to the rest of the European Union.

The aim of this paper is to explore the issue of tax ethics and tax evasion in order to identify in which situations tax evasion is accepted as ethical and which social groups consider tax evasion to be more acceptable. Moreover, we will analyze the tax ethics of Greek citizens and compare it to that of citizens from other countries. Regarding the contribution of our paper to academic research, we will use Robert McGee's questionnaire to measure tax evasion and tax ethics of Greek citizens. To our knowledge, no other research has been conducted having used an internationally recognized research tool to compare Greece to other countries and identify the characteristics of citizens which make them justify tax evasion.

The paper is structured as follows: first, the concepts of tax ethics and tax evasion are presented and a literature review is conducted. Next, we introduce the research methodology and present the research questions as well as the measurement instrument. Then the results of the empirical survey are presented. The paper concludes with the main conclusions, limitations and proposals for future research.

\section{Conceptual Framework}

Tax ethics refers to the tax payer's moral obligation to pay taxes and is affected by the relationship between the tax payer, as a citizen, and the government. Tax ethics and tax evasion are often used interchangeably. Tax evasion, however, refers to a person actively trying to avoid paying tax [5] while tax ethics refers to all non-monetary incentives to comply with tax legislation [6]. Measuring tax ethics helps to indirectly measure the size of "shadow economy", since not many individuals are willing to reveal whether they have committed financial irregularities or not. Consequently, a higher degree of tax ethics is positively related to regular tax payments and compliance to tax regulations. On the contrary, indi- 
viduals with a low degree of tax ethics are more prone to tax evasion [5]. Tax ethics is usually estimated through large-scale surveys that explore the values and beliefs of people, the way they change over time, and their social and political implications.

According to the Organization for Economic Cooperation and Development [7], the concept of tax evasion is generally used to describe illegal arrangements where tax liabilities are either hidden or ignored. In other words, the taxpayer pays less tax than he is legally obliged to pay by concealing income or information from the tax authorities. Tax fraud is a form of deliberate tax evasion and forms a criminal action. The term includes the deliberate misstatement of accounting information, falsification of documents, etc. Tax evasion is not the same as tax mitigation, which is the taxpayer's attempt to reduce his tax obligations or to avoid paying taxes by taking advantage of potential vague legislation, without, however, committing illegal actions. Tax evasion and has vast negative social and economic consequences, as it leads to uneven distribution of tax burdens and income and deprives states of their basic source of revenue. This results in governments raising existing tax levels, which in turn slows down economic growth and places additional burden to citizens who are consistent with their tax obligations. Summarizing, tax evasion negatively affects economic growth and raises social inequalities.

\section{Literature Review}

The attitude of citizens towards tax obligations is affected by various factors [6]. For example, several studies show that tax ethics is higher among older citizens, citizens who have strong religious beliefs or citizens who trust politicians. Moreover, international research has shown that tax ethics is positively related to tax system fairness and government transparency and negatively related to tax evasion and shadow economy [5].

In Portugal, a survey conducted by the European Values Study during the period 2008 to 2010 showed that behavioral, psychological and political factors have a direct impact on tax ethics. Fairness in the democratic political system and citizens' personal satisfaction with the system has a direct influence on tax ethics. Alternatively, citizens who believe that their political system is good have stronger tax ethics. On the other hand, there is a negative relationship between tax ethics, political participation and mistrust, i.e. citizens who are actively involved in politics and who do not trust others have weaker tax ethics [8]. In Turkey, trust in the state, religion, and national pride are positively related to compliance to social requirements such as tax payment. In other words, Turkish citizens who feel confident of social norms have a high level of tax ethics compared to those who do not [9].

In Spain, unlike Turkey, trust in the political system and religion do not have an effect on tax ethics. Nevertheless, national pride and a higher level of education have a positive impact on tax ethics [9]. In Russia, the World Value Survey 
research findings for the years 1999, 2006 and 2011 were analyzed over time, as significant changes have been made to the tax system and the way the state operates. The analysis showed a decrease in the level of tax ethics in recent years, which can be explained by the tax changes made in favor of the high income citizens. These changes have probably affected the tax ethics of the low income citizens and their desire to be consistent with their tax obligations.

In Pakistan, survey results show that women have significantly higher tax ethics than men. Similarly, pensioners comply more with tax legislation than non-pensioners while self-employed citizens have weaker tax ethics [10]. In Mauritania, similar to other surveys, married citizens and the elderly comply more with tax legislation compared to younger citizens. Moreover, justice, confidence in the government, and perceived fairness of how public money is spent improve the willingness of taxpayers to comply with tax requirements. Along those lines, tax compliance increases when citizens believe that the tax and legal system are fair, clear and stable, and corruption is being effectively tackled [11]. In Latvia, legitimacy of the tax authorities and the government, national pride and perception of the danger and severity of punishment were found to be positively related to high tax ethics for business owners and managers [12].

Finally, in a recent survey, in which data was collected from 35 Eurasian countries, tax ethics is higher in rich countries, in countries which have increased public revenues and expenditures, in countries with a fair and clear legal system and in countries with a low level of social inequality and corruption. Moreover, citizens of higher education and citizens with children have a higher sense of tax compliance [13].

\section{Research Methodology}

The purpose of this paper is to examine the perceptions of Greek taxpayers regarding tax evasion and to explore the circumstances under which tax evasion is accepted or considered acceptable. Moreover, we will compare the results of our survey with those of other countries and highlight the differences between the tax ethics of Greek citizens and those of citizens of other countries. A quantitative approach methodology was selected for this study. The participants were contacted via social media and email and were requested to answer an online questionnaire. The questionnaire used in this paper has been developed by Professor McGee and has been used as a research tool in various studies ([1] [14]-[22]). The questionnaire is still used in academic research [23]. In the first part of the questionnaire, participants were asked to respond to questions regarding demographic characteristics such as gender, occupational status, and level of education, marital and financial status. Then, they were asked to express their level of agreement/ disagreement to statements regarding tax evasion at a seven-step Likert type scale. The scale was rated as: 1-absolutely agree, 2-agree, 3-almost agree, 4-I am indifferent, 5-I almost disagree, 6-I disagree, 7-I totally disagree. 


\section{Survey Results}

\subsection{Demographic Characteristics}

A total of 500 questionnaires were sent via email and social media and 305 complete questionnaires were received representing a response rate of $61.00 \%$. To increase response rate three reminders were sent to each target respondent. The first was after one week from the initial email posting, the second after two weeks from the initial posting and the third after four weeks from the initial email posting. The collection of questionnaires began on the 10th of September 2017 and completed on the 20th of October 2017. The descriptive statistics of the final sample are presented on Table 1.

$61.3 \%$ of the sample respondents were men and $38.7 \%$ women. Regarding the occupational status, the majority were entrepreneurs $(34.4 \%)$, followed by private employees (23.9\%) and civil servants (23.3\%). In relation to the educational level, almost half of the participants had a bachelor's degree (49.5\%) and a large percentage had a postgraduate degree (33.8\%). Regarding the respondents'

Table 1. Demographics of respondents.

\begin{tabular}{|c|c|c|}
\hline Demographics of respondents & Frequency & $(\%)$ \\
\hline \multicolumn{3}{|l|}{ Gender } \\
\hline Male & 187 & $61.3 \%$ \\
\hline Female & 118 & $38.7 \%$ \\
\hline \multicolumn{3}{|l|}{ Occupation } \\
\hline Employee & 73 & $23.9 \%$ \\
\hline Civil Servant & 71 & $23.3 \%$ \\
\hline Entrepreneur & 105 & $34.4 \%$ \\
\hline Pensioner & 17 & $5.6 \%$ \\
\hline Unemployed & 16 & $5.2 \%$ \\
\hline Other & 23 & $7.5 \%$ \\
\hline \multicolumn{3}{|l|}{ Educational Level } \\
\hline Basic Education & 51 & $16.70 \%$ \\
\hline Bachelor's Degree & 151 & $49.5 \%$ \\
\hline Master's Degree & 103 & $33.8 \%$ \\
\hline \multicolumn{3}{|l|}{ Annual Income $(€)$} \\
\hline Up to 10,000 & 89 & $29.2 \%$ \\
\hline $10,000-30,000$ & 176 & $57.7 \%$ \\
\hline Over 30,000 & 32 & $13.1 \%$ \\
\hline \multicolumn{3}{|l|}{ Marital Status } \\
\hline Single & 112 & $36.70 \%$ \\
\hline Married & 193 & $63.30 \%$ \\
\hline
\end{tabular}


financial situation, the majority reported an annual income between $€ 10,000$ and $€ 30,000$ per year $(57.7 \%)$, followed by those who have a low income of up to $€ 10,000$ per year (29.2\%), while about $10 \%$ reported an annual income of more than $€ 30,000$ per year. Finally, regarding the marital status, 59.3\% were married and $36.7 \%$ were unmarried.

\subsection{Results of Descriptive Statistics}

The mean values of the survey items are presented below (Table 2). Items V05, V07 and V09 which correspond to the allocation of tax revenues according to the needs of the citizens, present mean values above 6, which means that Greek citizens tent to have strong tax ethics if they feel that there is a fair allocation of wealth on part of the state. On the other hand, items V04 and V11 and V14, which are associated with the misuse of public money, inefficiency of the tax system and corruption of the political system have received very low values, which means that tax ethics is negatively affected by injustice and maladministration. An interesting result is the fact that items V06 and V07, which examine

Table 2. Research Items and Mean Values.

\begin{tabular}{|c|c|c|}
\hline Code & Item & Mean \\
\hline V01 & Tax evasion is ethical if tax rates are too high. & 4.06 \\
\hline V02 & Tax evasion is ethical even if tax rates are not too high. & 5.78 \\
\hline V03 & Tax evasion is ethical if the tax system is unfair. & 4.17 \\
\hline V04 & $\begin{array}{l}\text { Tax evasion is ethical if a large portion of the money collected } \\
\text { by the public authorities is wasted. }\end{array}$ & 3.87 \\
\hline V05 & $\begin{array}{l}\text { Tax evasion is ethical even if most of the money collected is } \\
\text { properly allocated to the needs of the citizens. }\end{array}$ & 6.14 \\
\hline V06 & $\begin{array}{l}\text { Tax evasion is ethical if a large portion of the money collected is } \\
\text { spent on projects that I disapprove of. }\end{array}$ & 5.64 \\
\hline V07 & $\begin{array}{l}\text { Tax evasion is ethical even if a large portion of the money } \\
\text { collected is spent on projects that I approve of. }\end{array}$ & 6.00 \\
\hline V08 & $\begin{array}{l}\text { Tax evasion is ethical if a large portion of the money collected is } \\
\text { spent on projects that which are not beneficial to me. }\end{array}$ & 5.95 \\
\hline V09 & $\begin{array}{l}\text { Tax evasion is ethical if a large portion of the money collected is } \\
\text { spent on projects that which are beneficial to me. }\end{array}$ & 6.03 \\
\hline V10 & Tax evasion is ethical if everyone is doing it & 5.61 \\
\hline V11 & $\begin{array}{l}\text { Tax evasion is ethical if a significant portion of the money collected } \\
\text { winds up in the pockets of corrupt politicians or their families and friends. }\end{array}$ & 3.70 \\
\hline V12 & Tax evasion is ethical if the probability of getting caught is low. & 6.08 \\
\hline V13 & $\begin{array}{l}\text { Tax evasion is ethical if the tax collected is used to finance a war that } \\
\text { I consider being unjust. }\end{array}$ & 4.30 \\
\hline V14 & Tax evasion is ethical if I can't afford to pay. & 3.74 \\
\hline V15 & $\begin{array}{l}\text { Tax evasion is ethical even if other citizens will have to pay more tax } \\
\text { in order to cover for the loss of public revenue due to tax evasion. }\end{array}$ & 5.94 \\
\hline V16 & Tax evasion is ethical if I am not a citizen of the country in which I pay taxes. & 5.65 \\
\hline V17 & $\begin{array}{l}\text { Tax evasion is ethical if the government discriminates against me } \\
\text { because of my religion, race or ethnic background. }\end{array}$ & 5.27 \\
\hline V18 & $\begin{array}{l}\text { Tax evasion is ethical if the government imprisons people } \\
\text { for their political opinions. }\end{array}$ & 5.01 \\
\hline
\end{tabular}


the relationship between tax ethics and whether the respondent approves or disapproves a potential public funded project, have received similar rating on average. This means that Greek citizens do not link tax ethics with their own personal beliefs regarding the use of public money, as long as it is not wasted or abused. This is also supported by the mean values of items V08 and V09, which examine the relationship between tax ethics and the respondent's personal gains from the implantation of public projects. We observe that both items have received high mean values which furthers strengthens our claim that Greek citizens do not evade taxes due to potential personal gains but rather because they believe that the state is incapable of proper allocation of public money.

Finally, regarding the role of tax collection agencies, we observe that item V12, which corresponds to the relationship between tax evasion and tax audit, has also a very high mean value. This finding is particularly interesting because it shows that tax ethics is not necessarily affected by the severity of tax control, since most respondents believe that tax evasion is unethical despite the low chance of "being caught".

\subsection{Comparison with Other Countries}

This research was based on a questionnaire developed by Prof. Robert W. McGee, which has been used as a research instrument in similar studies. Table 3 presents the results of similar surveys that have been conducted in 8 different countries.

Compared to other countries, Greek citizens have less tolerance on tax evasion, with an average of 5.16, while the average of rest of the countries is 5.04. The country with the weakest tax ethics is Romania with an average of 4.59, while the country with the highest tax ethics appears to be Hong Kong, although data regarding the questions related to state discrimination are not provided. Taking into account all the items of the questionnaire, Guatemala is the country with the highest tax ethics rate. The question that has received the lowest ranking in all countries is the one related to corrupted politicians and abuse of public money. On the other hand, items V02 and V05 present the highest mean values in all countries, which means that tax ethics is positively affected by justice and efficiency in the tax system and proper allocation of public money.

Our results are in accordance to those of similar studies. In an empirical study by [24] regarding tax evasion, taxpayers' perceptions about the integrity of government officials, accountability and transparency have a significant impact on tax ethics. The same results are observed by [25], who also state that taxpayers are more likely to be consistent with their tax obligations if they believe that the government manages public money in an efficient and transparent manner. Regarding our research results, citizens are willing to pay more taxes if they believe that the government is using public money to enhance social welfare by financing projects that are beneficial not necessarily to the respondent himself but at least to the rest of the citizens. If this relationship is not clear, taxpayers are less 
Table 3. Comparing answers of Greeks of different ages and citizens of 8 countries.

\begin{tabular}{|c|c|c|c|c|c|c|c|c|c|}
\hline & Greece & Romania & Argentina & Hong Kong & Guatemala & Germany & Slovakia & Bosnia & India \\
\hline Item Code & & $\begin{array}{c}\text { McGee \& } \\
\text { Preobragenskaya } \\
\quad(2006)\end{array}$ & $\begin{array}{c}\text { McGee \& Rossi } \\
\quad(2006)\end{array}$ & $\begin{array}{c}\text { McGee \& Ho } \\
\text { (2006) }\end{array}$ & $\begin{array}{c}\text { McGee \& } \\
\text { Lingle (2006) }\end{array}$ & $\begin{array}{l}\text { McGee et al. } \\
\quad(2005)\end{array}$ & $\begin{array}{c}\text { McGee \& } \\
\text { Tusan (2008) }\end{array}$ & $\begin{array}{c}\text { McGee et al. } \\
\quad(2006)\end{array}$ & $\begin{array}{c}\text { McGee \& } \\
\text { Jain (2012) }\end{array}$ \\
\hline V01 & 4.06 & 4.17 & 4.80 & 5.30 & 5.20 & 6.38 & 5.34 & 5.06 & 4.69 \\
\hline V02 & 5.78 & 5.00 & 6.50 & 6.00 & 6.30 & 6.31 & 6.11 & 5.76 & 5.49 \\
\hline V03 & 4.17 & 3.87 & 4.40 & 4.50 & 4.50 & 6.21 & 4.89 & 3.93 & 3.72 \\
\hline V04 & 3.87 & 4.38 & 4.70 & 4.20 & 4.40 & 6.04 & 4.74 & 4.14 & 3.57 \\
\hline V05 & 6.14 & 4.80 & 6.60 & 4.40 & 6.30 & 6.00 & 5.91 & 6.09 & 5.93 \\
\hline V06 & 5.64 & 4.69 & 5.50 & 4.70 & 4.80 & 4.97 & 5.32 & 5.65 & 4.91 \\
\hline V07 & 6.00 & 4.72 & 6.10 & 6.40 & 5.80 & 5.72 & 5.89 & 6.11 & 5.85 \\
\hline V08 & 5.95 & 4.95 & 6.40 & 6.20 & 6.00 & 5.13 & 5.66 & 5.80 & 5.48 \\
\hline V09 & 6.03 & 4.86 & 6.50 & 6.50 & 6.30 & 5.07 & 4.61 & 6.09 & 5.71 \\
\hline V10 & 5.61 & 5.24 & 6.20 & 6.00 & 6.20 & 4.76 & 5.41 & 5.66 & 5.74 \\
\hline V11 & 3.70 & 4.18 & 4.20 & 3.70 & 3.70 & 4.48 & 4.04 & 3.44 & 3.61 \\
\hline V12 & 6.08 & 5.16 & 6.50 & 6.00 & 6.20 & 4.25 & 5.26 & 5.74 & 5.66 \\
\hline V13 & 4.30 & 4.45 & 4.80 & 4.00 & 4.90 & 4.24 & 4.89 & 4.66 & 4.85 \\
\hline V14 & 3.74 & 4.16 & 4.10 & 4.80 & 4.50 & 4.03 & 4.83 & 4.30 & 4.36 \\
\hline V15 & 5.94 & 5.03 & 6.30 & 6.00 & 6.10 & 3.69 & 5.38 & 5.81 & 5.57 \\
\hline V16 & 5.65 & 4.50 & 4.10 & & 4.00 & 3.65 & 2.80 & 4.89 & 4.27 \\
\hline V17 & 5.27 & 4.07 & 4.60 & & 4.30 & 3.59 & 3.35 & 3.44 & 4.03 \\
\hline V18 & 5.01 & 4.32 & 4.90 & & 4.70 & 3.41 & 3.95 & 3.92 & 4.37 \\
\hline Mean & 5.16 & 4.59 & 5.40 & 5.25 & 5.23 & 4.89 & 4.91 & 5.03 & 4.88 \\
\hline
\end{tabular}

likely to be consistent with their tax obligations, since they believe that their contribution to general prosperity does not benefit either themselves or their fellow citizens, but it is wasted through mismanagement and corruption [26].

\section{Conclusions}

Tax evasion is an economic and social phenomenon that has always been in the centre of public policy. Taxpayers commit tax evasion when they belief that public money is not allocated efficiently from the government to the citizens. Consequently, transparency is of outmost importance to taxpayers in order for them to believe that their contribution to public income is important and necessary. Therefore, it is very important for the state to have a legal framework that holds politicians accountable for their decisions and actions regarding the management of public money. Rebuilding the trust between the government and the citizens is perhaps the only solution to tackle tax evasion and this is where the current political system should focus its efforts on.

Comparing the results of our study with those of similar studies in other 
countries, we observe that there are no significant differences in the way tax ethics is being perceived by the citizens. Perhaps the only noticeable difference between Greece and the majority of the other countries analyzed in the present study is the fact that tax ethics receives higher mean values in all the questions regarding discrimination, which means that Greek citizens do not associate tax obligations with human rights and how the government interacts with citizens from different countries.

The current research instrument has been used to measure tax ethics is Greece for the first. We propose that further research should be conducted in order to make generalizations about this study's subject. The main constraint and limitation of the current research is the bias of the survey respondents. Future research should focus on a qualitative approach to understand the underlying factors that lead citizens to tax evasion. For example, in-depth interviews of different population groups could contribute into further understanding how tax evasion manifests itself in different social contexts.

\section{References}

[1] McGee, R.W. and Rossi, M.J. (2006) The Ethics of Tax Evasion: A Survey of Law and Business Students in Argentina. Proceedings of 6 th Annual International Business Research Conference, Jacksonville, Florida.

[2] Van Thiel, S. (2012) European Union Action against Tax Avoidance and Evasion. CESifo Forum, 13, 13.

[3] European Commission (2009) Promoting Good Governance in Tax Matters. Commission of the European Communities, Brussels.

[4] European Parliament (2017) General Tax Policy. http://www.europarl.europa.eu/atyourservice/en/displayFtu.html?ftuId=FTU_5.11. 1.html

[5] Torgler, B. and Schneider, F. (2009) The Impact of Tax Morale and Institutional Quality on the Shadow Economy. Journal of Economic Psychology, 30, 228-245. https://doi.org/10.1016/j.joep.2008.08.004

[6] Olsen, J., Kang, M. and Kirchler, E. (2012) Tax Psychology. In: Lewis, A., Ed., The Cambridge Handbook of Psychology and Economic Behavior, Cambridge University Press, Cambridge.

[7] Organization of Economic Cooperation and Development-OECD (2017) Glossary of Tax Terms. http://www.oecd.org/ctp/glossaryoftaxterms.htm

[8] Sá, C., Martins, A. and Gomes, C. (2015) Tax Morale Determinants in Portugal. European Scientific Journal, 11, 236-254.

[9] Bilgin, C. (2014) Determinants of Tax Morale in Spain and Turkey: An Empirical Analysis. European Journal of Government and Economics, 3, 60-74.

[10] Cyan, M.R., Koumpias, A.M. and Martinez-Vazquez, J. (2016) The Determinants of Tax Morale in Pakistan. Journal of Asian Economics, 47, 23-34. https://doi.org/10.1016/j.asieco.2016.09.002

[11] Vythelingum, P., Soondram, H. and Jugurnath, B. (2017) An Assessment of Tax Morale among Mauritian Taxpayers. Journal of Accounting and Taxation, 9, 1-10. https://doi.org/10.5897/JAT2016.0224

[12] Mickiewicz, T., Rebmann, A. and Sauka, A. (2017) To Pay or Not to Pay? Business 
Owners' Tax Morale: Testing a Neo-Institutional Framework in a Transition Environment. Journal of Business Ethics, 1-19.

[13] Williams, C.C. and Krasniqi, B. (2017) Evaluating the Individual- and Country-Level Variations in Tax Morale: Evidence from 35 Eurasian Countries. Journal of Economic Studies, 44, 816-832. https://doi.org/10.1108/JES-09-2016-0182

[14] McGee, R.W. and Preobragenskaya, G.G. (2006) The Ethics of Tax Evasion: A Survey of Romanian Business Students and Faculty. Accounting and Financial Systems Reform in Eastern Europe and Asia, 299-334.

[15] McGee, R.W. and Ho, S.S. (2006) The Ethics of Tax Evasion: A Survey of Accounting, Business and Economics Students in Hong Kong. Proceedings of International Academy of Business and Public Administration Disciplines (IABPAD), 2006 Winter Conference, Orlando, Florida, 3-6 January 2006. https://doi.org/10.2139/ssrn.869306

[16] McGee, R.W. and Lingle, C. (2008) The Ethics of Tax Evasion: A Survey of Guatemalan Opinion. In: Taxation and Public Finance in Transition and Developing Economies, Springer, Boston, MA, 481-495.

[17] McGee, R.W. and Jain, R.K. (2012) The Ethics of Tax Evasion: A Study of Indian Opinion. In: McGee, R., Ed., The Ethics of Tax Evasion, Springer, New York, 321-336. https://doi.org/10.1007/978-1-4614-1287-8_20

[18] McGee, R.W. and Tusan, R. (2008) The Ethics of Tax Evasion: A Survey of Slovak Opinion. In: McGee, R., Ed., Taxation and Public Finance in Transition and Developing Economies, Springer, Boston, MA, 575-601. https://doi.org/10.1007/978-0-387-25712-9_31

[19] McGee, R.W., Basic, M. and Tyler, M. (2006) The Ethics of Tax Evasion: A Survey of Bosnian Opinion. Proceedings of Fifteenth Annual World Business Congress of the International Management Development Association (IMDA), Sarajevo, Bosnia, 18-21 June2006. https://doi.org/10.2139/ssrn.899609

[20] McGee, R.W., Nickerson, I. and Fees, W. (2005) The Ethics of Tax Evasion: A Survey of German Business Students. Academy of Legal, Ethical and Regulatory, No. 33.

[21] McGee, R.W., Ho, S.S. and Li, A.Y. (2008) A Comparative Study on Perceived Ethics of Tax Evasion: Hong Kong vs the United States. Journal of Business Ethics, 77, 147-158. https://doi.org/10.1007/s10551-006-9304-1

[22] McGee, R.W. (1999) Is It Unethical to Evade Taxes in an Evil or Corrupt State? A Look at Jewish, Christian, Muslim, Mormon and Baha'i Perspectives. Journal of Accounting, Ethics \& Public Policy, 2, 149-181.

[23] Tarekegn, M. (2015) Ethics of Tax Evasion: Evidence from Self-Employed Tax-payers' of Dessie Town Administration, Ethiopia. Universal Journal of Accounting and Finance, 3, 153-170.

[24] Aronmwan, E.J., Imobhio, E. and Izedonmi, F. (2015) Determinants of Personal Income Tax Compliance: Perception of Nigerian Tax Payers. Available at SSRN 2619855. https://doi.org/10.2139/ssrn.2619855

[25] Ortega, D., Ronconi, L. and Sanguinetti, P. (2012) Reciprocity and Willingness to Pay Taxes: Evidence from a Survey Experiment in Latin America. Economía, 16, 55-87.

[26] Kiow, T.S., Salleh, M.F.M. and Kassim, A.A.B.M. (2017) The Determinants of Individual Taxpayers' Tax Compliance Behaviour in Peninsular Malaysia. International Business and Accounting Research Journal, 1, 26-43. https://doi.org/10.15294/ibarj.v1i1.4 